\title{
Disclosure Interactions and the Cost of Equity Capital: Evidence From the Spanish Continuous Market
}

\author{
Mónica Espinosa and Marco Trombetta*
}

\begin{abstract}
The purpose of this paper is to provide some new evidence on the relationship between disclosure and the cost of equity capital. We propose a new specification for the empirical test based on the idea that in the previous models one crucial variable was missing: accounting policy choice. We test our theoretical hypothesis using a sample of Spanish firms quoted on the Spanish continuous market from 1999 to 2002. We adopt the ex-ante approach to measure the cost of equity capital, taking analysts predictions as a proxy for expected earnings. As an explanatory variable we use an index measuring annual report disclosure quality. This measure of disclosure is combined with a proxy for the accounting policy choice of the firm. We measure firms' conservatism using the modified Jones model of Dechow et al. (1995) to estimate discretionary accruals. Our results confirm that the relationship between disclosure and cost of capital is affected by the choice of accounting policy.
\end{abstract}

Keywords: disclosure quality, cost of capital, accounting policy choice

\section{INTRODUCTION}

The extent to which firms benefit from increased disclosure is one of the most important issues in today's research in accounting. One of these advantages should be a reduction in the cost of equity capital. However, the empirical evidence on this matter is mixed.

The lack of conclusive results in this area may be due in part to two research design issues:

1. Measurement difficulties. Neither the cost of equity capital nor the quality of disclosure can be observed directly by the researcher. We have to rely on individual

\footnotetext{
*The authors are respectively from the Departamento de Economía Financiera, Contabilidad y Marketing, Universidad de Alicante, Spain and the Departamento de Economia de la Empresa, Universidad Carlos III de Madrid, Spain. They would like to thank Andrew Stark (editor) and an anonymous referee for their helpful comments. They would also like to thank Miles Gietzmann, Martin Walker and seminar participants at the III workshop on Empirical Research in Financial Accounting (Alicante, Spain) and at the University of Graz for their comments. All remaining errors are the authors' own responsibility. The financial support of the Spanish Ministry of Science and Technology through the grant SEC2001-0657 is gratefully acknowledged.
}

Address for correspondence: Marco Trombetta, Departamento de Economía de la Empresa, Universidad Carlos III de Madrid, Calle Madrid 126, E-28903 Getafe, Madrid, Spain.

e-mail: mtrombet@emp.uc3m.es 
perceptions and so testing for the relationship involves a significant degree of subjectivity.

2. Model specification issues. As suggested by Gietzmann and Trombetta (2003), the empirical tests used so far may suffer from a model specification problem, because they fail to consider the possible effect of different accounting policy choices.

This paper seeks to make a contribution to the literature on the effects of disclosure on cost of capital by directly addressing both of these issues.

To measure disclosure many authors use indexes, but the nature of these indexes varies considerably across the studies. While in some studies only voluntary disclosure activity is considered (Chow and Wong-Boren, 1987; and Raffournier, 1995), in others, both compulsory and voluntary disclosure is included in the index (Cooke, 1989; and Giner, 1997). Indexes based on annual report information are more focused on the quality of compulsory disclosure, whereas indexes based on voluntary additional communication activity tend to measure disclosure quantity.

Given that we consider only the information included in a firm's annual report, we focus more on the quality of the information disclosed. We create an index of quality of disclosure using data that are regularly published by a business magazine (Actualidad Económica) which studies the annual reports of the companies that trade on the Spanish continuous market.

With regard to the estimation of the cost of equity capital, we find two streams in the existing literature: ex-ante estimates, based on analysts forecasts, and an ex-post estimates, based on historical realised returns. Ex-post estimates have been heavily criticised for being inaccurate. ${ }^{1}$ For this reason a series of recent papers ${ }^{2}$ have proposed new proxies for the measurement of the cost of equity capital based on the actual stock price and analysts' forecasts of future earnings. In this paper, we follow this new strand of literature and estimate the ex-ante cost of equity capital using analysts' forecasts as proxies for market expectations.

The main purpose of our work is to test the empirical validity of the interaction equilibrium presented by Gietzmann and Trombetta (2003). The distinguishing feature of this equilibrium is that the cost of equity capital is jointly determined by disclosure quality and accounting policy choice. In this equilibrium, the lowest cost of equity is experienced by conservative companies regardless of their level of disclosure. On the other hand, aggressive companies can reduce their cost of capital by increasing the amount of information they disclose. This result could potentially explain the difficulty in finding a statistically significant inverse relationship between cost of equity capital and disclosure experienced, for example, by Botosan (1997) and Botosan and Plumlee (2002b). If accounting policy choice is relevant, then the relationship between the cost of equity capital and disclosure is not monotonic. It is negative for aggressive firms, but in the case of conservative firms no significant relationship is expected. Hence if we do not control for accounting policy choice in our empirical estimation of the model, then we may not expect to find a significantly negative coefficient for our proxy of disclosure. Figure 1 gives a graphical representation of this intuition. ${ }^{3}$

1 Cf. Elton (1999).

2 Some of them will be reviewed in the next section of the paper.

3 This figure was originally drawn by Miles Gietzmann. 
Figure 1

Disclosure and Cost of Capital

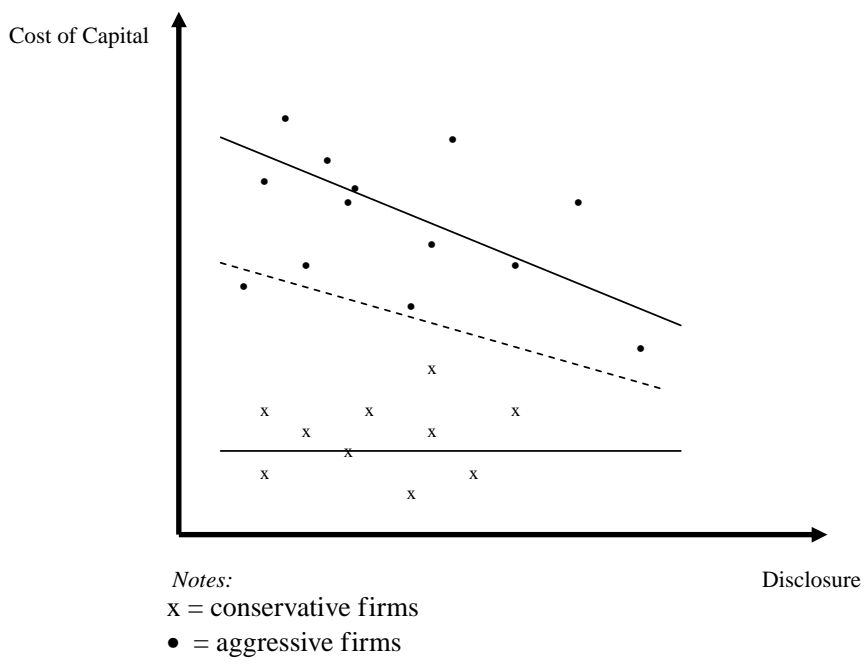

In the case depicted in Figure 1, if we estimate a simple regression of the cost of capital on disclosure, we may or may not find a statistical relationship because we are mixing two different models. For aggressive firms the relationship is clearly negative, whereas for conservative firms the relationship is flat.

The novelty of our work is the inclusion of a proxy for accounting policy choice, interacting with disclosure, in our empirical specification of the cost of capital model. We include in our model a dummy variable that differentiates between conservative and aggressive firms. We create this dichotomous variable using the modified Jones model of Dechow et al. (1995) of discretionary accruals. In line with related research, such as Givoly and Hayn (2000) and Gietzmann and Ireland (2005) we classify as conservative (aggressive) those firms making negative (positive) accruals. ${ }^{4}$

Accounting policy choice has significant explanatory power in determining the relationship between cost of equity capital and disclosure. In the case of aggressive firms the relationship is negative as expected. On the other hand, for conservative firms, disclosure is not a significant determinant of the cost of capital. We interpret this as positive evidence in support of the existence of the interaction equilibrium theoretically predicted by Gietzmann and Trombetta (2003). ${ }^{5}$

The remainder of the paper is organized as follows. In Section 2 we review the relevant related literature. In Section 3 we present our hypotheses and our research

4 We have also used a self-constructed measure of earnings conservatism calculated by looking directly at companies' annual reports. The results are similar to those obtained with discretionary accruals and are omitted here

5 In a related paper Gietzmann and Ireland (2005) test the same hypothesis using a sample of UK companies. Our work differs from theirs in terms of the variables used. They measure disclosure quantity in a specific sector using a news database, whereas our measure of disclosure refers to disclosure quality in the context of the annual report. They also find positive evidence in favour of the existence of the interaction equilibrium. 
design. Section 4 presents our empirical results. Finally, Section 5 provides some conclusions.

\section{RELATED RESEARCH}

The relation between cost of equity capital and disclosure has been investigated in recent years by several theoretical and empirical studies. From the theoretical point of view it has been argued that disclosure reduces information asymmetry, and consequently reduces firms' cost of equity capital. However, empirical results are mixed and depend crucially on the metrics of disclosure and cost of equity capital.

By revealing private information, firms try to address the reluctance of potential investors to hold shares in illiquid markets, and thus, reduce the cost of equity capital. Following this line of argument, Diamond and Verrecchia (1991) show that companies reduce their cost of equity by improving disclosure, which implies higher liquidity of firms' securities and increases the demand from large investors.

Another possible benefit of better disclosure quality is that better information reduces potential investors estimation risk regarding the parameters of a security's future return or payoff distribution. It is assumed that investors attribute more systematic risk to an asset with low information than to an asset with high information (Handa and Linn, 1993; Klein and Bawa, 1976; Coles et al., 1995; and Clarkson et al., 1996)

There are quite a few empirical studies that have dealt with the effect of disclosure on the cost of equity capital. Botosan (1997) shows that among firms attracting a low analyst following, those that present higher-quality disclosures benefit from lower levels of cost of capital. She uses a sample of 115 firms and measures cost of capital using a version of the residual income valuation model. Botosan and Plumlee (2002b) estimate cost of capital using four alternative methods, and they find that after controlling for firm size and market beta, more timely disclosure is associated with a lower cost of capital. Hail (2002), using a similar technique to Botosan (1997), shows for a crosssectional sample of 73 non-financial Swiss firms a negative and highly significant relation between the cost of equity capital and disclosure. This result holds in general, even for firms with high analyst following. Leuz and Verrechia (2001) find that increased disclosure, proxied by the adoption of international accounting standards strategy rather than local GAAP, implies lower bid-ask spreads and higher share turnover, after controlling for several firm characteristics. In this line, Welker (1995) also document a significant negative relation between financial analysts' disclosure rankings and respectively a firm's bid-ask spread. Healy et al.(1999) show that stock performance and capital market intermediation is improved when voluntary disclosure increases. Others, like Marquardt and Wiedman (1998) provide evidence that managers believe that increasing voluntary disclosure reduces information asymmetry and consequently the cost of capital. However, none of these studies takes into account the accounting policy choice as a determinant of the cost of equity capital.

Two streams of literature focus on cost of capital estimation: on the one hand, we can find studies that use past realized returns (ex-post approach) and on the other hand, we have several studies that use analysts' forecasts (ex-ante approach).

The ex-post approach is open to a number of criticisms. Fama and French (1997) conclude that such cost of capital estimates are imprecise and identify three potential 
problems associated with the use of past realized returns to compute risk premia: (i) difficulties in identifying the right asset pricing model, (ii) imprecision in the estimates of factor loadings, and (iii) imprecision in the estimates of factor risk premia. ${ }^{6}$

These problems with the ex-post approach have prompted the search for alternative proxies for the cost of equity capital. There are several studies that adopt an ex-ante perspective, such as Botosan and Plumlee (2002a), Gebhardt et al. (2001), Claus and Thomas (2001) and Gode and Mohanram (2002). ${ }^{7}$ They compute the implied cost of capital for each firm as the internal rate of return that equates the theoretical value of the firm as calculated by some multi-period valuation model and the current stock price. To do this it is necessary to forecast accounting variables (mainly earnings and book value) up to a terminal period and to establish a suitable terminal value to capture the value of these accounting variables beyond the terminal period. Even if the general methodology is common to all the papers that adopt the ex-ante approach, various formulas for the calculation of the empirical proxy for the cost of equity capital have been proposed, depending on the valuation model adopted and on the assumptions made about its future evolution and terminal value.

Guay et al. (2003) perform a comparative analysis of four of the ex-ante empirical proxies for the cost of equity capital and of the classic Fama and French (1997) three factor ex-post measure. As metrics for their comparative analysis they use the ability of each cost of equity capital proxy to predict one-year, two-year and three-year ahead returns. Using a sample of US stocks from 1982 to 2000 they find that: (a) the Fama and French (1997) ex-post measure is not able to significantly predict future returns and suffers from considerable estimation error; (b) that on average the measure proposed by Gebhardt et al. (2001) performs relatively better with respect to the other ex-ante measures in predicting future returns. For this reason we decided to use only ex-ante measures of the cost of equity capital.

Studies that have conducted a comparative analysis of the various alternative ex-ante proxies for the cost of equity capital show that they are all highly correlated and that in most cases the differences between them are not statistically significant. ${ }^{8}$ Hence among the possible ex-ante measures of the cost of equity capital we will use only two: the measure proposed by Gebhardt et al. (2001) and the average between the same Gebhart et al. (2001) measure and the three measures used by Easton and Monahan (2003).

\section{HYPOTHESIS DEVELOPMENT AND RESEARCH DESIGN}

\section{(i) Hypothesis Development}

The adverse selection problem, associated with information asymmetries, gives rise to transaction costs when shares are bought and sold. Firms with higher levels of asymmetries of information show reduced levels of liquidity in their shares, and so buyers are more reluctant to acquire them. Improving the quality of disclosure reduces the possibilities of information asymmetry, and hence, the adverse selection problem.

6 Elton (1999) also provides criticism for the ex-post approach.

7 Easton et al. (2002) also use the residual income valuation model but to estimate simultaneously the expected cost of capital and the growth rate.

8 See, for example, Chen et al. (2004), Guay et al. (2003) and Hail and Leuz (2003). For a more detailed discussion of this topic see Trombetta (2004). 
It should consequently improve investors' capabilities in forecasting future growth and therefore reduce the estimation risk and information asymmetry components of a firm's cost of equity capital.

Following this line of argument we can state the following 'classic' hypothesis:

$\mathrm{H}_{1}$ : There is a negative association between the cost of equity capital and the quality of firm disclosures in the annual report.

However, the relationship between cost of capital and disclosure can be more complex. For instance, Botosan (1997) finds no statistically significant relationship between cost of equity capital and disclosure for her full sample, although she finds a significantly negative relationship for firms with a low analyst following. The above mentioned hypothesis may depend crucially on the accounting policy chosen by the firm. The adoption of aggressive accounting policies may look risky to investors. So, the market might penalize firms that adopt an aggressive accounting policy by charging them a higher cost of equity capital. This fact can induce more voluntary disclosure by aggressive firms wanting to assure the market of their good prospects. As shown by Gietzamnn and Trombetta (2003) accounting policy choice can be used as a signalling device that affects the cost of equity capital. Firms with better future prospects can separate from firms with worse future prospects by choosing a conservative accounting policy mix. Hence conservative accounting reduces the cost of equity capital. However, once the accounting policy (signalling) phase of the game has taken place, firms can still influence their cost of capital by their disclosure decisions. Aggressive firms can try to reduce their cost of equity capital by being more transparent, whereas conservative firms can decide that their cost of equity capital is already sufficiently low and avoid the cost involved in disclosing information to the general public.

We therefore test the following hypothesis:

$\mathrm{H}_{2}$ : There exists a significant negative relationship between the cost of equity capital and quality of disclosure in the annual report for firms adopting an aggressive accounting policy, while there is no relationship between the cost of equity capital and quality of disclosure in the annual report for firms with a conservative accounting policy.

\section{(ii) Sample and Variables}

\section{(a) Sample Selection}

Initially we considered all the non-financial companies of the Spanish continuous market for which we have disclosure data for years 1998 to 2001 inclusive. Given that the effects of disclosure will be perceived after the publication of the annual report, we estimate our measures of cost of equity capital at the end of June of each year 1999, 2000, 2001 and 2002 respectively.

We exclude from our sample all companies for which some of the necessary data to obtain our estimates of the cost of equity capital are missing, such as analysts' forecasts of EPS.

Lately, we delete from the sample all observations with missing values for any of the variables used in our empirical analysis or necessary to estimate discretionary accruals. The details of our sample selection can be found in Table 1. 
Table 1

Summary of Sample Selection Procedures

\begin{tabular}{lrrrrrr}
\hline & 2002 & 2001 & 2000 & 1999 & Total & Percent \\
\hline Firms with disclosure score available & 121 & 124 & 117 & 158 & 520 & 100 \\
Financial institutions & 21 & 20 & 20 & 26 & 87 & 16.7 \\
Missing data to estimate cost of capital & 31 & 25 & 33 & 31 & 120 & 23.1 \\
Missing additional variables & 6 & 15 & 18 & 24 & 63 & 12.1 \\
TOTAL & 63 & 64 & 46 & 77 & 250 & 48.1 \\
\hline
\end{tabular}

Our final sample consists of 250 firm-year observations, from the period 19982002. Given that the same company can be present in each year of the pooled sample our observations are not independent over time. We will deal with this problem by running the same regressions year by year and aggregating the results using the method proposed by Fama and Macbeth (1973).

The Spanish market is an interesting case to study, because it has undergone a massive process of modernization in the past few years. A few facts may help to capture the scope of this change. In terms of market capitalization its annual average growth rate between 1991 and 2001 has been 21\%. Hence the market in 2001 was six times bigger than in 1991. More interesting is the evolution of the distribution of share ownership. In 1992 $16.64 \%$ of the traded shares were in the hands of the State and only $1.65 \%$ were owned by funds, and $7.72 \%$ were owned by other non financial companies. In 2001, due to the privatization process, the share of the State had gone down to $0.21 \%$, whereas the share owned by non financial companies had reached the level of $21.73 \%$. Moreover, the quota controlled by funds had gone up to $4.86 \%$. Finally, the quota owned by foreign investors increased from $30.61 \%$ in 1991 to $35 \%$ in 2001.

In such a fast growing market the issue of the determinants of the cost of equity capital is of particular importance given that the number of private, institutional and foreign investors acquiring shares has increased. For this reason the importance of fundamental research and transparency in valuation should have increased.

On the other hand, it is still a market where 'families'control almost $28 \%$ of the shares. So it is not obvious that disclosure could play a crucial role in determining the cost of equity capital in a market where a consistent number of transactions is still arranged on a personal basis. Hence, if we find that disclosure plays a crucial role in such a market, then we might expect it to play an even bigger role in bigger markets.

Accounting policy choice is a key variable to be considered in the study of the financial performance of a firm, an in particular, in studying its relation with the financial communication strategy of a firm. Givoly and Hayn (2000) argue that anecdotal evidence suggests that financial reporting has become more conservative in recent years. Garcia Lara and Mora (2004) provide evidence on the existence of both balance sheet and earnings conservatism in Europe. They argue that Spain, as is the rest of continental countries, more likely to show balance sheet conservatism.

As a preliminary check on the existence of conservatism in our sample, we test the magnitude of the reaction of earnings to good and bad news. We use Basu's (1997) reverse regression, taking negative and positive unexpected annual stock returns as a proxy for bad and good news. He argues that under a conservative environment, earnings are timelier or more sensitive in reflecting publicly available bad news than 
Table 2

Earnings Conservatism

Basu (1997)

$$
\frac{X_{t}}{P_{t-1}}=\alpha+\beta_{1} D+\beta_{2} R_{t}+\beta_{3} D R_{t}+\varepsilon_{t}
$$

\begin{tabular}{lccccc}
\hline & Intercept & $\beta_{1}$ & $\beta_{2}$ & $\beta_{3}$ & Adj. $R^{2}$ F-statistic \\
\hline Coefficient & 0.08 & 0.01 & -0.01 & 0.13 & 0.11 \\
P-value & $(0.0000)$ & $(0.56)$ & $(0.63)$ & $(0.00)$ & $(0.0000)$ \\
\hline
\end{tabular}

Notes:

$X_{t}$ is earnings after extraordinary items per share, $P_{t-1}$ is share price at the beginning of the period, $R_{t}$ is the rate of return of the firm from 9 months before fiscal year end $t$ to three months after fiscal year end, $D$ is a dummy variable which has a value of 1 in the case of bad news (that is, negative or zero rate of return) and 0 otherwise.

good news. To test this idea, he proposes the following model:

$$
\frac{X_{t}}{P_{t-1}}=\alpha+\beta_{1} D+\beta_{2} R_{t}+\beta_{3} D R_{t}+\varepsilon_{t}
$$

where $X_{t}$ is earnings after extraordinary items per share, $P_{t-1}$ is share price at the beginning of the period, $R_{t}$ is the rate of return of the firm from nine months before fiscal year end $t$ to three months after fiscal year end, $D$ is a dummy variable which has a value of 1 in the case of bad news (that is, a negative or zero rate of return) and 0 otherwise.

The coefficient of the interaction term, $\beta_{3}$, measures the differential sensitivity of earnings to bad news. So, we can affirm that there exists earnings conservatism in Spain, if it is significantly positive.

The results obtained from estimating the Basu (1997) reverse regression in our sample are shown in Table 2. Effectively, we have empirical evidence of the existence of earnings conservatism, because the coefficient of the interaction term $\beta_{3}$ is 0.13 and significant at the $1 \%$ level.

The existence of conservatism and the modernization and growth process experienced by the Spanish market, give us an interesting framework to study the consequences that disclosure and the accounting policy have on firms' cost of capital.

\section{(b) Estimation of the Implied Cost of Equity Capital}

Our dependent variable is the cost of equity capital. As explained above we use two measures of the ex-ante cost of equity capital, both based on forecasted future earnings. First, we use the measure proposed by Gebhart et al. (2001) and based on the residual income valuation model. According to this model the stock price can be expressed as the reported book value, plus an infinite sum of discounted residual incomes:

$$
P_{t}=b v_{t}+\sum_{\tau=1}^{+\infty} \frac{x_{t+\tau}-r b v_{t+\tau-1}}{(1+r)^{\tau}}
$$


where:

$P_{t}=$ closing price at time $t$

$b v_{t}=$ book value at time $t$

$x_{t}=$ earnings at time $t$

$r=$ cost of equity capital.

However, for practical purposes, an explicit forecast period must be defined. Moreover, a 'terminal value' also needs to be determined, that is, an estimate of the value of the firm after the explicit forecasting period.

Following the methodology proposed by Gebhardt et al. (2001), we use a three-stage approach to compute intrinsic value: (1) Firstly, we use explicit earnings forecasts for the next three years; (2) Secondly, we obtain earning forecasts by linearly fading year $t+3$ return on equity (ROE) to the mean market ROE by year $t+T$; (3) Finally, we assume that the latest residual income is a perpetuity to calculate terminal value.

We compute the following finite horizon estimate for each firm:

$$
P_{t}=b v_{t}+\sum_{\tau=1}^{3} \frac{\hat{x}_{t+\tau}-r_{e} \hat{b} v_{t+\tau-1}}{\left(1+r_{e}\right)^{\tau}}+\sum_{\tau=4}^{12} \frac{\hat{x}_{t+\tau}-r_{e} \hat{b} v_{t+\tau-1}}{\left(1+r_{e}\right)^{\tau}}+\frac{\hat{x}_{t+13}-r_{e} \hat{b} v_{t+12}}{r_{e}\left(1+r_{e}\right)^{12}}
$$

where:

$P_{t} \quad=$ closing price of the month of June

$\hat{x}_{t+\tau}=$ analysts' consensus forecasts for one, two and three years ahead EPS; beyond year $t+3$, earnings are forecasted by linearly fading actual ROE to a median market ROE by year $t+12$

$r_{e} \quad=$ estimate of the ex ante cost of equity capital

$\hat{b} v_{t+\tau}=$ expected future accounting book value at date $t+\tau$, assuming the clean surplus relation. Expected future net dividends for period $(t+\tau-1, t+\tau)$ are obtained using the firm's average dividend payout ratio over the last five years.

We solve this relationship by an iterative process ${ }^{9}$ and produce an estimate of the $e x-$ ante cost of capital conditioned on the currently available information. We will call this estimate $r_{r i v}$.

After having calculated the Gebhart et al. (2001) proxy, using the same set of data we compute the other three measures of the ex-ante cost of equity capital. All three alternatives proxies for the ex-ante cost of equity capital are based on the valuation model developed by Ohlson and Juetter-Nauroth (2001) also known as the Abnormal Earnings Growth Valuation Model. The general valuation formula according to this model is as follows:

$$
P_{t}=\frac{x_{t+1}}{r}+\sum_{\tau=2}^{+\infty} \frac{x_{t+\tau}+r d_{t+\tau-1}-(1+r) x_{t+\tau-1}}{r}=\frac{x_{t+1}}{r}+\sum_{\tau=2}^{+\infty} \frac{\mathrm{AEG}_{t+\tau}}{r(1+r)^{\tau}} .
$$

All the variables are defined as before, apart from $d_{t}$, which is the dividend payout at time $t$, and $\mathrm{AEG}_{t}$ which is the Abnormal Earnings Growth rate at time $t$.

9 This is done using the Mathematica ${ }^{(\mathcal{C}}$. 
Starting from this general valuation formula, each of the three proxies is obtained by making some restrictive assumptions on the parameters of the model. ${ }^{10}$ The expressions for each of the three measures are as follows:

Price to Forward Earnings model (PEF)

$$
P_{t}=\frac{\hat{x}_{t+1}+r_{e} d_{t+1}+\hat{x}_{t+2}}{\left(r_{e}+1\right)^{2}-1}
$$

Price to Earnings Growth model (PEG)

$$
P_{t}=\frac{\hat{x}_{t+2}-\hat{x}_{t+1}}{\left(r_{e}\right)^{2}}
$$

Modified Price to Earnings Growth models (MPEG)

$$
P_{t}=\frac{\hat{x}_{t+2}+r_{e} d_{t+1}-\hat{x}_{t+1}}{\left(r_{e}\right)^{2}} .
$$

We will call the cost of equity capital estimates obtained by using equations (5), (6) and (7) $r_{p e f}, r_{p e g}$ and $r_{\text {mpeg }}$ respectively.

Finally, we calculate the average of the four estimates $\left(r_{r i v}, r_{p e f}, r_{p e g}, r_{m p e g}\right)$ and we call it $r_{\text {avrg }}$. Distributional statistics and correlation coefficients for the cost of equity capital estimates are provided in Table 3.

The correlation among the five estimates is always positive and significant. This result, which is in line with previous studies, confirms the idea that even if the absolute values of the various estimates can be quite different, the choice of a particular estimate instead of another should not change the results of the analysis too dramatically. This is the case for our sample and for the sake of brevity we will present the results only for $r_{\text {riv }}$ and $r_{\text {avrg }}$. However, we notice the presence of very extreme values, especially for the $r_{r i v}$ estimates. In order to produce more reliable results we winsorize the extreme values using $4 \%$ as the minimum value and $35 \%$ as the maximum value. ${ }^{11}$

\section{(c) Disclosure Data}

Our disclosure quality proxy is based on the data regularly published by a business magazine (Actualidad Económica) that studies the annual reports of the companies that trade on the Spanish continuous market.

Several items are graded by a pool of experts in order to produce a score that measures the quality of the information provided in the annual report. Among them we find: historical data, analytical account of results, composition of shareholding, shares percentage held by the board of directors, order and clarity of the report, design, number of branches, directors' remuneration, returns on shares, market evolution, review of operations and on-line information. ${ }^{12}$

10 Given that the aim of our paper is not to test the specific properties of each of the three estimates, we do not present the specific derivation of each of the three expressions. The interested reader can refer to Easton and Monahan (2003) or Chen et al. (2004).

11 We would like to thank an anonymous referee for suggesting this.

12 The full list of items can be found in the Appendix. 
Table 3

Distributional Statistics for Implied Cost of Capital Estimates

\section{Panel A: Distributional Statistics on Cost of Capital Estimates}

Percentile

\begin{tabular}{lcrrrrrrr}
\cline { 6 - 7 } Variable & $N$ & Mean & Min. & $Q_{1}$ & $Q_{2}$ & $Q_{3}$ & Max. & St. Dev. \\
\hline$r_{\text {riv }}$ & 250 & 9.41 & 1.52 & 7.05 & 8.68 & 10.62 & 85.96 & 6.27 \\
$r_{p f e}$ & 247 & 8.16 & 0.33 & 5.35 & 7.35 & 9.87 & 26.38 & 4.26 \\
$r_{\text {peg }}$ & 250 & 10.40 & 0.00 & 7.48 & 9.67 & 12.19 & 43.38 & 6.21 \\
$r_{m p e g}$ & 250 & 12.70 & 0.00 & 8.94 & 10.91 & 13.84 & 79.42 & 8.55 \\
$r_{\text {avrg }}$ & 250 & 10.14 & 2.52 & 7.39 & 9.00 & 11.67 & 34.08 & 4.73 \\
\hline
\end{tabular}

Panel B: Spearman Correlation Coefficients among Cost of Capital Estimates

\begin{tabular}{lcccc} 
Variable & $r_{\text {riv }}$ & $r_{p f e}$ & $r_{p e g}$ & $r_{m p e g}$ \\
\hline$r_{p f e}$ & $0.81^{* * *}$ & & & \\
$r_{p e g}$ & $0.53^{* * *}$ & $0.41^{* * *}$ & & \\
$r_{m p e g}$ & $0.54^{* *}$ & $0.54^{* * *}$ & $0.90^{* * *}$ & \\
$r_{\text {avrg }}$ & $0.77^{* * *}$ & $0.72^{* * *}$ & $0.84^{* * *}$ & $0.92^{* * *}$ \\
\hline
\end{tabular}

Notes:

$r_{r i v}$ is the cost of capital estimate obtained from the Residual Income Valuation Model; $r_{p e f}$, is the estimate obtained from the Price to Forward Earnings Model; $r_{p e g}$ is obtained from the Price to Earnings Growth Model; $r_{m p e g}$, derives from the Modified Price to Earnings Growth Model. All these estimates are obtained by making some restrictive assumptions on the parameters of the Abnormal Earnings Growth Valuation Model. Finally, $r_{\text {avrg }}$, is the average of the previously mentioned four estimates.

*** Significant at the $1 \%$ level.

A score is given for each one of these items of the annual report. With these scores we have created a disclosure index based on the sum of scores obtained divided by the maximum sum of scores obtainable. For example, CEPSA in 2000 was given a total score of 54, and as the maximum available was 100 points, the index of quality of disclosure takes the total value 0.54. Contrary to the case of the AIMR score used in most US based studies, for the Spanish case the grading of annual reports is made by the same pool of experts for all the companies included in the study. Moreover, the list of items graded is also the same for the whole sample analysed. This guarantees consistency across firms and industries.

\section{(d) Accounting Policy}

Our objective is to distinguish between aggressive and conservative mixes of accounting policy choices. Our main measure is based on the modified Jones model as presented by Dechow et al. (1995) for discretionary accruals. Accounts data are obtained from the COMPUSTAT database. ${ }^{13}$

We obtain discretionary accruals (DA) from total accruals (TA), which are defined as the difference between operating income and operating cash-flows. Following the modified Jones model of Dechow et al. (1995), we first calculate TA from the equation:

$$
\mathrm{TA}_{t}=\Delta\left(\mathrm{CA}_{t}-\mathrm{CASH}_{t-1}\right)-\Delta\left(\mathrm{CL}_{t}-\mathrm{CBORR}_{t}\right)-\mathrm{DEPN}_{t}
$$

13 Givoly and Hayn (2000) also rely on accruals to differentiate between aggressive and conservative firms. 
where:

CA $=$ current assets

$\mathrm{CASH}=$ cash and cash equivalents

$\mathrm{CL}=$ current liabilities

CBORR = current portion of long-term debt

DEPN = depreciation and amortization expense.

Once we obtain $T A$, the following model of non discretionary accruals is estimated:

$$
\operatorname{NDA}_{t}=\beta_{1}\left(\frac{1}{\operatorname{ASSETS}_{t-1}}\right)+\beta_{2}\left(\frac{\Delta \operatorname{REV}_{t}}{\operatorname{ASSETS}_{t-1}}-\frac{\Delta \mathrm{REC}_{t}}{\operatorname{ASSETS}_{t-1}}\right)+\beta_{3}\left(\frac{\operatorname{PPE}_{t-1}}{\operatorname{ASSETS}_{t-1}}\right)+\varepsilon_{t}
$$

where:

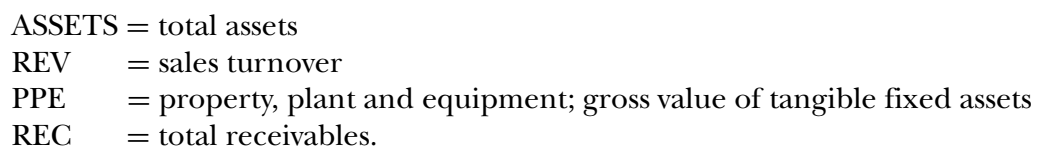

Using the coefficients obtained from this regression we can obtain DA as the difference between TA and NDA, that is:

$$
\begin{aligned}
\mathrm{DA}_{t}= & \frac{\mathrm{TA}_{t}}{\operatorname{ASSETS}_{t-1}}-\hat{\beta}_{1}\left(\frac{1}{\operatorname{ASSETS}_{t-1}}\right)-\hat{\beta}_{2}\left(\frac{\Delta \mathrm{REV}_{t}}{\operatorname{ASSETS}_{t-1}}-\frac{\Delta \mathrm{REC}_{t}}{\operatorname{ASSETS}_{t-1}}\right) \\
& -\hat{\beta}_{3}\left(\frac{\operatorname{PPE}_{t-1}}{\operatorname{ASSETS}_{t-1}}\right) .
\end{aligned}
$$

Finally, we define our alternative accounting policy choice variable as a dummy which has a value of one for firms making positive DA (considered as aggressive ones) and zero for conservative firms (those making negative DA).

We have also calculated a second proxy for accounting policy choice. In order to create this alternative variable, we pay attention to some accounting issues that could be the object of the discretion of managers, so that they could affect profits. In particular, we consider four types of provisions: general provisions for risk, inventory provisions, bad financial investment provisions and bad debt provisions. For each company in each year the value of this provision has been divided respectively by total liabilities, total inventory, total financial assets and receivables. Then we obtain the median values for each of these ratios on each year. Finally, we create a dummy variable whose value is zero if three or four firm's provisions are located above their median values and one otherwise. The intuition behind our proxy is that firms showing higher values in their provisions ratios may intend to reduce their annual earnings more than firms with lower provisions ratios and this can be interpreted as a more conservative accounting policy.

We use both measures to differentiate between aggressive and conservative firms, and with both of them we obtain similar results. However, given that our own measure of conservativism is highly subjective and given that the results are stronger with the more universally accepted measure based on discretionary accruals, we decided to present 
only the results obtained with the dummy derived from the modified Jones model of accruals.

\section{(e) Other Independent Variables}

The ex-ante implied cost of capital is just an empirical proxy of the unobservable cost of equity capital. One way to justify its validity is to study its relationship with other variables that reflect risk factors of the firm as perceived by investors. This is the approach taken by, for example, Botosan and Plumlee (2002a), Gebhardt et al. (2001), Hail (2002) and Chen et al. (2004). Our choice of control variables has been guided by the list of variables used in these previous studies.

We consider the following risk characteristics in our analysis:

Leverage: A firm's cost of equity should be an increasing function of the amount of debt in its capital structure, because debt increases the volatility of future earnings. Several empirical works such as Hail (2002), Botosan and Plumlee (2002a) or Gebhardt et al. (2001), document this positive relation. However, whether leverage is seen as good or bad news by investors is not clear from the perspective of the asymmetries of information. As a measure of market leverage we use total liabilities over market capitalization. These data have been obtained from the COMPUSTAT database.

Beta: The Capital Asset Pricing Model (CAPM) suggests that a stock's market beta should be positively correlated with its cost of capital. However, previous studies do not consistently show such an expected relationship. This is the case of Gebhardt et al. (2001), while others like Hail (2002) confirm the expected positive sign for the Swiss market. We obtain beta of each stock using a market model for the 60 months prior to the month $t$, requiring at least, 12 monthly return observations.

Size: Firm size could be used as a proxy for availability of information, because information is more available for larger firms than for smaller ones. As long as companies provide more information, future earnings are perceived by investors to have lower risk, and this implies a lower cost of capital. We expect this effect to be even stronger in a developing market such as the Spanish stock market. Therefore, we expect a lower cost of capital for larger firms than for smaller ones. As a proxy for size we use the natural logarithm of market capitalization.

\section{EMPIRICAL ANALYSIS}

\section{(i) Correlation Analysis}

In Table 4 we provide distributional statistics for our control variables and the correlation coefficients between our dependent and independent variables. We observe that, as we expected, disclosure is negatively correlated with both cost of equity capital proxies. This result provides some preliminary evidence in favour of hypothesis $\mathrm{H}_{1}$ : the ex ante cost of equity capital is decreasing in disclosure quality.

Moreover, the cost of equity capital is increasing in leverage, and it is inversely related to company size. This result provides validity to both our measures of the cost of equity capital. No significant correlation is observed between our proxy for risk (Beta) and the cost of equity capital. 
Table 4

Descriptive Statistics for the Control Variables

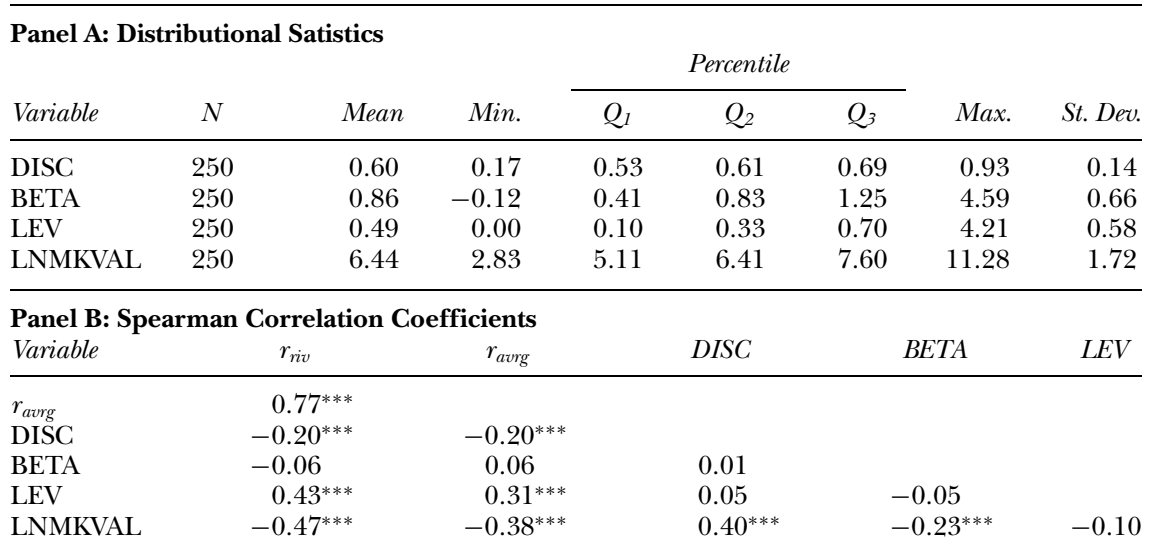

Notes:

$r_{\text {riv }}$ and $r_{\text {avrg }}$ are the estimates of the cost of equity capital. DISC is our index of quality of disclosure obtained for years 1998, 1999, 2000 and 2001. BETA is estimated via a market model regression requiring at least 12 monthly return observations in the five-year period ended June 30, from 1999 to 2002. LEV is the ratio of total debt to market value of outstanding equity at the beginning of each year. LNMKVAL is the natural logarithm of market value of equity at the beginning of each year.

*** Significant at the $1 \%$ level.

(ii) Multivariate Analysis

\section{(a) 'Classic' Model}

As mentioned above, most of the companies in our sample are repeated from one year to the other. This is the reason why in addition to ordinary OLS regression on the pooled data, we will also run yearly regressions to calculate Fama and Macbeth (1973) average coefficients and $t$ statistics.

First of all we run the following 'classic' cost of capital and disclosure regression in order to test hypothesis $\mathrm{H}_{1}$ :

$$
r_{t}=\alpha+\beta_{1} \mathrm{DISC}_{t-1}+\beta_{2} \mathrm{BETA}_{t}+\beta_{3} \mathrm{LEV}_{t-1}+\beta_{4} \mathrm{LNMKVAL}_{t-1}+\varepsilon_{t}
$$

where:

$$
\begin{array}{ll}
r & =\text { proxy for the ex-ante cost of equity capital }\left(r_{r i v}, r_{\text {avrg }}\right) \\
\text { DISC } & =\text { index of annual report disclosure quality } \\
\text { BETA } & =\text { market beta } \\
\text { LEV } & =\text { leverage ratio } \\
\text { LNMKVAL } & =\text { Natural logarithm of market capitalization. }
\end{array}
$$

Table 5 shows the results of running this regression. These results confirm the validity of the two measures of the ex-ante cost of equity capital. Both with the pooled sample and with the Fama and Macbeth coefficients, size and leverage have the expected significant 
Table 5

'Classic' Model: Full Sample

$r_{t}=\alpha+\beta_{1} \mathrm{DISC}_{t-1}+\beta_{2} \mathrm{BETA}_{t}+\beta_{3} \mathrm{LEV}_{t-1}+\beta_{4} \mathrm{LNMKVAL}_{t-1}+\varepsilon_{t}$

\begin{tabular}{lccccc}
\hline & \multicolumn{2}{c}{ Pooled } & & \multicolumn{2}{c}{ Fama and McBeth } \\
\cline { 2 - 3 } \cline { 5 - 5 } Dependent Variable & $r_{\text {riv }}$ & $r_{\text {avrg }}$ & & $r_{\text {riv }}$ & $r_{\text {avrg }}$ \\
\hline Intercept & 14.14 & 12.76 & & 13.34 & 17.39 \\
& $(12.11)$ & $(4.47)$ & & $(26.33)$ & $(6.68)$ \\
DISC & -2.33 & 1.29 & & -2.20 & -0.93 \\
& $(-1.41)$ & $(0.31)$ & & $(-0.92)$ & $(-0.37)$ \\
BETA & 0.27 & 5.79 & & 1.28 & 1.13 \\
& $(0.83)$ & $(1.75)$ & & $(1.34)$ & $(0.70)$ \\
LEV & 2.08 & 2.95 & & 2.69 & 2.35 \\
& $(5.63)$ & $(3.43)$ & & $(2.45)$ & $(2.18)$ \\
LNMKVAL & -0.74 & -0.82 & & -0.77 & -1.14 \\
& $(-5.29)$ & $(-2.48)$ & & $(-11.61)$ & $(-3.23)$ \\
$R^{2}$ (adj. $)$ & 0.27 & 0.27 & & 0.38 & 0.28 \\
P(F-Stat) & $(0.00)$ & $(0.00)$ & & \\
\hline
\end{tabular}

Notes:

$r_{\text {riv }}$ and $r_{\text {avrg }}$ are the estimates of the cost of equity capital. DISC is our index of quality of disclosure obtained for years 1998, 1999, 2000 and 2001. BETA is estimated via a market model regression requiring at least 12 monthly return observations in the five-year period ended June 30, from 1999 to 2002. LEV is the ratio of total debt to market value of outstanding equity at the beginning of each year. LNMKVAL is the natural logarithm of market value of equity at the beginning of each year.

$n=250 ; t$-statistics in brackets.

sign on the cost of equity capital. In the previous literature on the cost of equity capital, these two factors have been consistently shown to have an effect on each possible proxy for this variable. Beta is not significant, but this is also in line with the previous literature where the results about beta as a determinant of the cost of equity capital are mixed.

With respect to hypothesis $\mathrm{H}_{1}$, disclosure has the expected negative sign in all regressions but one. However, the coefficient is never significantly different from zero. Overall we must conclude that the null of $\mathrm{H}_{1}$ is not rejected and that there is no significant inverse relationship between annual report disclosure quality and the cost of equity capital. However, as proposed theoretically by Gietzmann and Trombetta (2003), the cost of equity capital may be jointly determined by disclosure quality and the accounting policy choice of the firm.

Firms implementing an aggressive accounting policy may look suspicious to investors; therefore the market might penalize them by charging a higher cost of capital. So, we expect companies with conservative accounting policies to show a lower cost of equity capital than aggressive firms. This fact however, may induce aggressive firms to provide better information to the market in an attempt to reduce the negative effect of accounting policy choice on the cost of equity capital. Hence, firms with aggressive accounting policies could reduce their cost of equity capital by increasing their disclosure. This is the theoretical argument behind our hypothesis $\mathrm{H}_{2}$.

In order to test hypothesis $\mathrm{H}_{2}$, we run regression (11) for two separate sub-samples: one that includes only 109 companies classified as aggressive and another that includes 
Table 6

'Classic' Model: Sub-sample of Aggressive Firms

$$
r_{t}=\alpha+\beta_{1} \mathrm{DISC}_{t-1}+\beta_{2} \mathrm{BETA}_{t}+\beta_{3} \mathrm{LEV}_{t-1}+\beta_{4} \mathrm{LNMKVAL}_{t-1}+\varepsilon_{t}
$$

\begin{tabular}{lccccc}
\hline & \multicolumn{2}{c}{ Pooled } & & \multicolumn{2}{c}{ Fama and McBeth } \\
\cline { 2 - 3 } Dependent Variable & $r_{\text {riv }}$ & $r_{\text {avrg }}$ & & $r_{\text {riv }}$ & $r_{\text {avrg }}$ \\
\hline Intercept & 15.44 & 16.89 & & 15.55 & 16.00 \\
& $(9.60)$ & $(8.86)$ & & $(8.60)$ & $(5.71)$ \\
DISC & -6.07 & -8.43 & & -4.65 & -5.66 \\
& $(-2.49)$ & $(-2.92)$ & & $(-6.76)$ & $(-2.09)$ \\
BETA & -0.41 & 0.23 & & -0.67 & 2.35 \\
& $(-0.95)$ & $(0.45)$ & & $(-0.33)$ & $(1.14)$ \\
LEV & 2.23 & 1.38 & & 3.67 & 2.97 \\
& $(4.58)$ & $(2.39)$ & & $(1.66)$ & $(1.35)$ \\
LNMKVAL & -0.50 & -0.47 & & -0.59 & -0.56 \\
& $(-2.26)$ & $(-1.81)$ & & $(-3.17)$ & $(-2.10)$ \\
$R^{2}$ (adj.) & 0.29 & 0.21 & & 0.47 & 0.37 \\
P $(F$-Stat $)$ & $(0.00)$ & $(0.00)$ & & \\
\hline
\end{tabular}

Notes:

$r_{r i v}$ and $r_{\text {avrg }}$ are the estimates of the cost of equity capital. DISC is our index of quality of disclosure obtained for years 1998, 1999, 2000 and 2001. BETA is estimated via a market model regression requiring at least 12 monthly return observations in the five-year period ended June 30, from 1999 to 2002. LEV is the ratio of total debt to market value of outstanding equity at the beginning of each year. LNMKVAL is the natural logarithm of market value of equity at the beginning of each year.

$n=109 ; t$-statistics in brackets.

only the 141 companies classified as conservative. In order to divide our full sample into the two sub-samples we have used discretionary accruals calculated by using the modified Jones model: companies with positive discretionary accruals are classified as aggressive and companies with non-positive accruals are classified as conservative.

Table 6 shows the results for the aggressive sub-sample and Table 7 shows the results for the conservative sub-sample. As we can see from these two tables, the same model works in a quite different way in the two sub-samples. In the case of aggressive firms (Table 6) disclosure quality always has the expected negative sign and it is always significant.

Turning our attention the sub-sample of conservative firms (Table 7) we can see that the classical determinants of the cost of equity capital (LEV and LNMKVAL) are always significant with the expected sign, whereas disclosure quality is never significant and it always has a positive sign. These results provide some preliminary evidence in favour of hypothesis $\mathrm{H}_{2}$. Disclosure may reduce the cost of equity capital for firms that adopt an aggressive accounting policy, but does not affect the cost of equity capital for firms that adopt a conservative accounting policy.

\section{(b) Full Interaction Model}

We now move to a second test of hypothesis $\mathrm{H}_{2}$. In order to check whether accounting policy choice and disclosure interact in determining a firm's cost of equity capital we 


\section{Table 7}

'Classic' Model: Sub-sample of Conservative Firms

$$
r_{t}=\alpha+\beta_{1} \mathrm{DISC}_{t-1}+\beta_{2} \mathrm{BETA}_{t}+\beta_{3} \mathrm{LEV}_{t-1}+\beta_{4} \mathrm{LNMKVAL}_{t-1}+\varepsilon_{t}
$$

\begin{tabular}{lccccc}
\hline & \multicolumn{2}{c}{ Pooled } & & \multicolumn{2}{c}{ Fama and McBeth } \\
\cline { 2 - 3 } \cline { 5 - 6 } Dependent Variable & $r_{\text {riv }}$ & $r_{\text {avrg }}$ & & $r_{\text {riv }}$ & $r_{\text {avrg }}$ \\
\hline Intercept & 12.71 & 17.02 & & 11.80 & 16.53 \\
& $(7.69)$ & $(7.71)$ & & $(8.33)$ & $(4.49)$ \\
DISC & 0.49 & 0.64 & & 0.02 & 2.08 \\
& $(0.22)$ & $(0.22)$ & & $(0.01)$ & $(0.97)$ \\
BETA & 1.06 & -0.52 & & 1.70 & 0.94 \\
& $(2.22)$ & $(-0.82)$ & & $(1.26)$ & $(0.84)$ \\
LEV & 1.85 & 2.09 & & 2.90 & 2.77 \\
& $(3.27)$ & $(2.79)$ & & $(2.31)$ & $(2.06)$ \\
LNMKVAL & -0.87 & -1.14 & & -0.46 & -1.28 \\
& $(-4.80)$ & $(-4.76)$ & & $(-1.02)$ & $(-2.56)$ \\
$R^{2}$ (adj.) & 0.52 & 0.23 & & 0.44 & 0.29 \\
P(F-Stat) & $(0.00)$ & $(0.00)$ & & \\
\hline
\end{tabular}

\section{Notes:}

$r_{\text {riv }}$ and $r_{\text {avrg }}$ are the estimates of the cost of equity capital. DISC is our index of quality of disclosure obtained for years 1998, 1999, 2000 and 2001. BETA is estimated via a market model regression requiring at least 12 monthly return observations in the five-year period ended June 30, from 1999 to 2002. LEV is the ratio of total debt to market value of outstanding equity at the beginning of each year. LNMKVAL is the natural logarithm of market value of equity at the beginning of each year.

$n=141 ; t$-statistics in brackets.

run the following interaction regression model on our full sample:

$$
\begin{aligned}
r_{t}= & \alpha+\beta_{1} \text { DISC }_{t-1}+\beta_{2} \text { BETA }_{t}+\beta_{3} \mathrm{LEV}_{t-1}+\beta_{4} \text { LNMKVAL }_{t-1}+\beta_{5} \text { DAGG }_{\mathrm{t}-1} \\
& +\beta_{6} \text { DAGG }_{t-1} * \text { DISC }_{t-1}+\beta_{7} \text { DAGG }_{t-1} * \text { BETA }_{t-1}+\beta_{8} \text { DAGG }_{t-1} * \text { LEV }_{t-1} \\
& +\beta_{9} \text { DAGG }_{t-1} * \text { LNMKVAL }_{t-1}+\varepsilon_{t}
\end{aligned}
$$

where:

$r \quad=$ proxy for the ex-ante cost of equity capital $\left(r_{r i v}, r_{a v r g}\right)$

DISC = index of annual report disclosure quality

BETA $=$ market beta

LEV = leverage ratio

LNMKVAL $=$ Natural logarithm of market capitalization

DAGG = Dummy variable that takes value 1 for aggressive firms (positive discretionary accruals) and 0 otherwise.

The results concerning this model can be found in Table 8 .

As expected the coefficients of the classic part of the model are the same as the coefficients for the regression of the classic model on the sub-sample of conservative firms. So the comments will not be repeated here. However, it is important to stress again that for conservative firms there is no evidence of an impact of disclosure on the cost of equity capital. 


\section{Table 8}

\begin{tabular}{|c|c|c|c|c|}
\hline $\begin{aligned} r_{t}= & \alpha+\beta_{1} \mathrm{DISC} \\
& +\beta_{6} \mathrm{DAGG} \\
& +\beta_{9} \mathrm{DAGG}\end{aligned}$ & $\begin{array}{r}\text { Full } \\
{ }_{2} \mathrm{BETA}_{t} \\
\mathrm{SC}_{t-1}+ \\
\mathrm{MKVAL}_{t}\end{array}$ & $\begin{array}{l}\text { ion Mod } \\
T_{t-1}+\beta_{4} \\
t_{t-1} * \mathrm{BE}\end{array}$ & $\begin{array}{l}\mathrm{AL}_{t-1}+ \\
\beta_{8} \mathrm{DAG}\end{array}$ & $\begin{array}{l}\mathrm{G}_{\mathrm{t}-1} \\
\mathrm{EV}_{t-1}\end{array}$ \\
\hline & & & Fam & Beth \\
\hline Dependent Variable & $r_{r i v}$ & $r_{\text {avrg }}$ & $r_{\text {riv }}$ & $r_{\text {avrg }}$ \\
\hline Intercept & $\begin{array}{l}12.71 \\
(7.69)\end{array}$ & $\begin{array}{l}17.02 \\
(8.13)\end{array}$ & $\begin{array}{l}11.80 \\
(8.33)\end{array}$ & $\begin{array}{l}16.53 \\
(4.49)\end{array}$ \\
\hline DISC & $\begin{array}{c}0.49 \\
(0.22)\end{array}$ & $\begin{array}{c}0.64 \\
(0.23)\end{array}$ & $\begin{array}{c}0.02 \\
(0.01)\end{array}$ & $\begin{array}{c}2.08 \\
(0.97)\end{array}$ \\
\hline BETA & $\begin{array}{c}1.06 \\
(2.24)\end{array}$ & $\begin{array}{c}-0.52 \\
(-0.86)\end{array}$ & $\begin{array}{c}1.69 \\
(1.26)\end{array}$ & $\begin{array}{c}0.94 \\
(0.84)\end{array}$ \\
\hline LEV & $\begin{array}{c}1.85 \\
(3.30)\end{array}$ & $\begin{array}{c}2.09 \\
(2.94)\end{array}$ & $\begin{array}{c}2.90 \\
(2.31)\end{array}$ & $\begin{array}{c}2.77 \\
(2.06)\end{array}$ \\
\hline LNMKVAL & $\begin{array}{c}-0.87 \\
(-4.85)\end{array}$ & $\begin{array}{c}-1.14 \\
(-5.02)\end{array}$ & $\begin{array}{c}-0.85 \\
(-4.77)\end{array}$ & $\begin{array}{c}-1.28 \\
(-2.56)\end{array}$ \\
\hline DAGG & $\begin{array}{c}2.73 \\
(1.18)\end{array}$ & $\begin{array}{c}-0.13 \\
(-0.04)\end{array}$ & $\begin{array}{c}3.74 \\
(1.27)\end{array}$ & $\begin{array}{c}-0.53 \\
(-0.15)\end{array}$ \\
\hline DAGG $*$ DISC & $\begin{array}{c}-6.56 \\
(-1.97)\end{array}$ & $\begin{array}{c}-9.07 \\
(-2.15)\end{array}$ & $\begin{array}{c}-4.67 \\
(-1.99)\end{array}$ & $\begin{array}{c}-7.75 \\
(-2.80)\end{array}$ \\
\hline DAGG $*$ BETA & $\begin{array}{c}-1.47 \\
(-2.28)\end{array}$ & $\begin{array}{c}0.75 \\
(0.91)\end{array}$ & $\begin{array}{c}-2.36 \\
(-0.76)\end{array}$ & $\begin{array}{c}0.16 \\
(0.10)\end{array}$ \\
\hline DAGG $*$ LEV & $\begin{array}{c}0.38 \\
(0.50)\end{array}$ & $\begin{array}{c}-0.71 \\
(-0.75)\end{array}$ & $\begin{array}{c}0.77 \\
(0.62)\end{array}$ & $\begin{array}{c}0.20 \\
(0.08)\end{array}$ \\
\hline DAGG $*$ LNMKVAL & $\begin{array}{c}0.37 \\
(1.30)\end{array}$ & $\begin{array}{c}0.67 \\
(1.84)\end{array}$ & $\begin{array}{c}0.25 \\
(0.76)\end{array}$ & $\begin{array}{c}0.72 \\
(1.78)\end{array}$ \\
\hline $\begin{array}{l}R^{2} \text { (adj.) } \\
\mathrm{P}(F-\text { Stat })\end{array}$ & $\begin{array}{c}0.29 \\
(0.00)\end{array}$ & $\begin{array}{c}0.22 \\
(0.00)\end{array}$ & 0.44 & 0.36 \\
\hline
\end{tabular}

Notes:

$r_{\text {riv }}$ and $r_{\text {avrg }}$ are the estimates of the cost of equity capital. DISC is our index of quality of disclosure obtained for years 1998, 1999, 2000 and 2001. BETA is estimated via a market model regression requiring at least 12 monthly return observations in the five-year period ended June 30, from 1999 to 2002. LEV is the ratio of total debt to market value of outstanding equity at the beginning of each year. LNMKVAL is the natural logarithm of market value of equity at the beginning of each year. DAGG is a dummy variable which value is one for aggressive firms and zero for conservatives.

$n=250 ; t$-statistics in brackets.

When we turn our attention to the interaction part of the regression model we can notice that the coefficient of the accounting policy choice dummy on its own is never statistically different from zero. Hence, there is no evidence of any fixed effect of being aggressive on the cost of equity capital.

However, the coefficient on the interaction term between accounting policy choice and disclosure always has the expected negative sign and it is always statistically significant. This result provides evidence in favour of the hypothesis that aggressive companies use disclosure in order to reduce the asymmetric information component of the cost of equity capital. If we combine this result with the absence of a direct effect of disclosure for conservative firms highlighted before, we can conclude that our results provide positive evidence in favour of the existence of the interaction equilibrium proposed by Gietzmann and Trombetta (2003). Moreover, disclosure is 
the only independent variable for which the interaction effect is consistently significant across the various estimations.

\section{CONCLUSIONS}

The objective of our study was to investigate the relationship between disclosure and cost of equity capital. In particular we test for the existence of the interaction equilibrium of the theoretical model proposed by Gietzmann and Trombetta (2003). Firms may reduce the adverse selection component of their cost of equity capital through two possible communication channels: the choice of a specific accounting policy among the options left open by accounting regulation and the choice of the level of disclosure of other value relevant information. Gietzamnn and Trombetta (2003) show that these two communication channels may interact in the sense that disclosure choice may depend on accounting policy choice in a significant way. Firms that adopt conservative accounting policies may not feel the need to add additional disclosures given that their 'quality' has already been communicated through the choice of the least advantageous accounting policy. On the other hand, firms that adopt aggressive accounting policies can use the disclosure channel in order to mitigate the negative effects that the choice of the most advantageous accounting policy may have created in the market for equity capital.

In order to test our hypothesis we use a sample of Spanish quoted companies for which we have disclosure data between 1998 and 2001. The Spanish market is well suited for running this test because despite its rapid growth in the recent past, it is still relatively small and run by families. Hence it is a market where the cost of equity capital should not be too reactive to companies' disclosure policies. As a consequence if we find positive evidence in favour of a 'disclosure effect' in such a market, the effect should be even stronger in more developed equity markets.

The interaction between accounting policy choice and disclosure can also provide a possible explanation of the mixed results obtained so far in the empirical literature with respect to the supposed positive effect of transparency on the cost of equity capital: accounting policy may be an omitted variable in the model estimated so far.

Our results confirm this idea. First, we estimated a 'classic' model of the relationship between disclosure and cost of equity capital without taking into account accounting policy choice. With this model we are not able to find any significant evidence in favour of an inverse relationship between disclosure and the cost of equity capital. However, when we take into account accounting policy choice, proxied by the sign of discretionary accruals, we find that the inverse relationship exists for aggressive firms, whereas it is not significant for conservative firms. This empirical evidence supports the need to always consider a wider specification of the communication strategy of a company. To focus only on one communication channel, either disclosure or accounting numbers may be misleading because these two channels do seem to interact in a significant way.

\section{APPENDIX}

Our key independent variable is a measure of the quality of the companies' annual report disclosures produced by a well known business magazine (ActualidadEconómica). The following is the list of the items considered by the magazine while computing the score. 
The President's Letter: If it is signed during the first quarter of the year, it gets one point. The contents of the letter may be awarded up to 5 points if a clear definition of the company's strategy is outlined. (Scale: from 0 to 6 points.)

Historical Data: 2 points if the main data for year $t-2$ of the profit and loss account and of the balance-sheet appear. 4 points if those for year $t-3$ are also included, and 6 if those for year $t-4$ appear as well. (Scale: from 0 to 6 points.)

Basic Data: 8 points if a summary of the main data of the accounts, financial ratios and market ratios appear. Both the quantity and the quality of the data are evaluated. (Scale: From 0 to 8 points.)

Analysis of Results: Full analysis of the operations, mean total assets, quarterly results analysis of year $t$ compared to year $t-1$ are given up to 6 points. If only data for year $t$ are included, 4 points are given. (Scale: from 0 to 6 points.)

The Management's Report: 6 points, if all legally required information is included: i.e., the evolution of the business and of the current situation of the company, events that occurred after the closing of the audit, the evolution of the company, its purchases of its own shares and $\mathrm{R}+\mathrm{D}$ activities. The clarity and the quantity of the information is awarded up to 12 points. (From 0 to 12 points.)

Order and Clarity: the clarity, conciseness and precision of the language are valued here, as well as whether the information follows a logical order. (From 0 to 3 points.)

Design: The quality of the design and its graphics and pictures. (From 0 to 2 points.)

Affiliates: Two points for information about the activity, home, participation, own funds and results of different affiliates. 4 points if the dividends received by the affiliates and their book-values are included. 6 points if the accounts are included. (From 0 to 6 points.)

Segmental Reporting: Break-down of the business by categories of activities and geographical markets. A complete analysis of the contribution to the overall results for each of these areas is rewarded with 4 points. (From 0 to 4 points.)

The Audit: 4 points for audits without qualifications, 2 for those that contain qualifications and zero if the auditor indicates limitations or reserves his opinion. The cost of the audit is evaluated on a 2-point scale. (From 0 to 6 points.)

Shareholders: 2 points if it gives information about the shareholders who hold more than $10 \%$ of the firm's total stock. 4 points if the percentage of total capital is specified, and 6 if any additional information is included. (From 0 to 6 points.)

Board of Directors: 2 points for information on the shares held by the board. 4 points if the participation of some of its members is also specified, and 6 if it is detailed. (From 0 to 6 points.)

Directors' Remuneration: If there is global information on the total remuneration 2 points are given. 4 points if there is a breakdown. 6 points if the breakdown of Directors' remuneration is done nominally. (From 0 to 6 points.)

Stock Options Plans: A description of the plans, beneficiaries, conditions, cost to the company and other characteristics. To achieve the maximum points, the options 
granted to their executives and directors must be broken-down by individual. (From 0 to 4 points.)

Other Information: up to 4 points are granted to companies that offer excellent information on their true situation. The degree of concentration of sales and suppliers; their market-share; a market analysis; the volume of distribution channels, or, information on either quality or environmental initiatives, are some of the items considered here. (From 0 to 4 points.)

On-line Information: The inclusion of the annual report in the company's web page is evaluated on a two-point scale. If quarterly reports are also included it is added 2 more points. (From 0 to 4 points.)

Good Policy Norms: A complete and detailed declaration of the firm's norms and policies. To achieve the maximum points, the company must explain to what degree it has managed to implement the recommendations included in the Spanish good governance ('Olivencia') Report. (From 0 to 5 points.)

Evolution of the Market: 3 points if information is included on the evolution of the interest-rate, recruiting volume and days of trading. 4 if market ratios are included. 5 if the rate is compared to the general Stock Market index or the Ibex35, and 6 if it also includes the sector's index. (From 0 to 6 points.)

\section{REFERENCES}

Basu, S. (1997), 'The Conservatism Principle and the Asymmetric Timeless of Earnings', Journal of Accounting and Economics, Vol. 24, No. 1, pp. 3-37

Botosan, C. A. (1997), 'Disclosure Level and the Cost of Equity Capital', The Accounting Review, Vol. 72, No. 3, pp. 323-49.

- and M. A. Plumlee (2002a), 'Assessing the Construct Validity of Alternative Proxies for Expected Cost of Equity Capital' (http://ssrn.com/abstract=310181). (2002b), 'A Re-examination of Disclosure Level and the Expected Cost of Equity Capital', Journal of Accounting Research, Vol. 40, No. 1, pp. 21-40.

Chen, F., B. N. Jorgensen and Y. K. Yoo (2004), 'Implied Cost of Equity Capital in Earningsbased Valuation: International Evidence', Accounting and Business Research, Vol. 34, No. 4, pp. 323-44.

Chow, C. W. and A. Wong-Boren (1987), 'Voluntary Financial Disclosure by Mexican Corporations', The Accounting Review, Vol. 62, No. 3, pp. 533-41.

Clarkson, P., J. Guedes and R. Thompson (1996), 'On the Diversification, Observability, and Measurement of Estimation Risk', Journal of Financial and Quantitative Analysis, Vol. 31, No. 1, pp. 69-84.

Claus, J. and J. Thomas (2001), 'Equity Risk Premium as Low as Three Percent? Evidence from Analysts' Earnings Forecasts for Domestic and International Stocks', Journal of Finance, Vol. 56, No. 5, pp. 1629-66.

Coles, J. L., U. Loewenstein and J. Suay (1995), 'On Equilibrium Pricing Under Parameter Uncertainty', Journal of Financial and Quantitative Analysis, Vol. 30, No. 3, pp. 347-64.

Cooke, T. E. (1989), 'Disclosure in the Corporate Annual Reports of Swedish Companies', Accounting and Business Research, Vol. 19, No. 74, pp. 113-24.

Dechow, P. M., R. G. Sloan and A. P. Sweeney (1995), 'Detecting Earnings Management', The Accounting Review, Vol. 70, No. 2, pp. 193-225.

Diamond, D. E. and R. E. Verrechia (1991), 'Disclosure, Liquidity, and the Cost of Capital', Journal of Finance, Vol. 46, No. 4, pp. 1325-59.

Easton, P. and S. Monahan (2003), 'An Evaluation of the Reliability of Accounting Based Measures of Expected Returns: A Measurement Error Perspective' (http://ssrn. com/abstract $=433801)$. 
Easton, P., G. Taylor, P. Shroff and T. Sougiannis (2002), 'Using Forecasts of Earnings to Simultaneously Estimate Growth and the Rate of Return on Equity Investment', Journal of Accounting Research, Vol. 40, No. 3, pp. 657-76.

Elton, E. J. (1999), 'Expected Returns, Realized Returns and Asset Pricing Tests', The Journal of Finance, Vol. 54, No. 4, pp. 1199-220.

Fama, E. F. and K. French (1997), 'Industry Costs of Equity', Journal of Financial Economics, Vol. 33, No. 1, pp. 3-57.

- and J. D. MacBeth (1973), 'Risk, Return, and Equilibrium: Empirical Tests', Journal of Political Economy, Vol. 81, No. 3, pp. 607-36.

Garcia-Lara, J. M. and A. Mora (2004), 'Balance Sheet versus Earnings Conservatism in Europe', European Accounting Review, Vol. 13, No. 2, pp. 261-92.

Gebhardt, W. R., C. M. Lee and B. Swaminathan (2001), 'Toward an Implied Cost-of-Capital', Journal of Accounting Research, Vol. 39, No. 1, pp. 135-76.

Gietzmann, M. and J. Ireland (2005), 'Cost of Capital, Strategic Disclosures and Accounting Choice', Journal of Business Finance E $\mathcal{E}$ Accounting, Vol. 32, Nos 9 \& 10, pp. 599-634.

- and M. Trombetta (2003), 'Disclosure Interactions: Accounting Policy Choice and Voluntary Disclosure Effects on the Cost of Rising Outside Capital', Accounting and Business Research, Vol. 33, No. 3, pp. 187-205.

Giner, B. (1997), 'The Influence of Company Characteristics and Accounting Regulation on Information Disclosed by Spanish Firms', European Accounting Review, Vol. 6, No. 1, pp. $45-68$.

Givoly, D. and C. Hayn (2000), 'The Changing Time-series Properties of Earnings, Cash Flows and Accruals: Has Financial Reporting Become More Conservative?', Journal of Accounting and Economics, Vol. 29, No. 3, pp. 287-320.

Gode, D. and P. Mohanram (2002), 'Inferring the Cost of Capital Using the Ohlson-Juettner Model', Working Paper (New York, Stern School of Business).

Guay, W. R., S. P. Kothari and S. Shu (2003), 'Properties of Implied Cost of Capital Using Analysts' Forecasts', MIT Sloan Working Paper No. 4422-03 (http://ssrn. com/abstract $=426560)$.

Hail, L. (2002), 'The Impact of Voluntary Corporate Disclosures of the Ex-ante Cost of Capital for Swiss Firms', European Accounting Review, Vol. 11, No. 4, pp. 741-73.

- and C. Leuz (2003), 'International Differences in the Cost of Equity Capital: Do Legal Institutions and Securities Regulation Matter?' ECGI - Law Working Paper No. 15/2003 (http://ssrn.com/abstract=437603).

Handa, P. and S. C. Linn (1993), 'Arbitrage Pricing with Estimation Risk', Journal of Financial and Quantitative Analysis, Vol. 28, No. 1, pp. 81-100.

Healy, P. M., A. P. Hutton and K. G. Palepu (1999), 'Stock Performance and Intermediation Changes Surrounding Sustained Increases in Disclosure', Contemporary Accounting Research, Vol. 16, No. 3, pp. 485-520.

Klein, R. W. and V. S. Bawa (1976), 'The Effect of Estimating Risk on Optimal Portfolio Choice', Journal of Financial Economics, Vol. 3, No. 3, pp. 215-31.

Leuz, C. and R. E. Verrechia (2001), 'The Economic Consequences of Increased Disclosure', Journal of Accounting Research, Vol. 38, Supplement, pp. 91-124.

Marquardt, C. A. and C. I. Wiedman (1998), 'Voluntary Disclosure, Information Asymmetry, and Insider Selling Through Secondary Equity Offerings', Contemporary Accounting Research, Vol. 15, No. 4, pp. 505-37.

Ohlson, J. A., and B. E. Juettner-Nauroth (2001), 'Expected EPS and EPS Growth as Determinants of Value', Working Paper (New York University).

Raffournier, B. (1995), 'The Determinants of Voluntary Financial Disclosure by Swiss Listed Companies', European Accounting Review, Vol. 4, No. 2, pp. 261-80.

Trombetta, M. (2004), 'Implied Cost of Equity Capital in Earnings-based Valuation: International Evidence. Discussion', Accounting and Business Research, Vol. 34, No. 4, pp. 345-48.

Welker, M. (1995), 'Disclosure Policy, Information Asymmetry, and Liquidity in Equity Markets', Contemporary Accounting Research, Vol. 11, No. 2, pp. 801-27. 